University of Nebraska - Lincoln

DigitalCommons@University of Nebraska - Lincoln

Papers in the Earth and Atmospheric Sciences Earth and Atmospheric Sciences, Department

$12-1892$

\title{
Notice of the Occurrence of Nyctale richardsoni, Richardson's Owl, in Nebraska
}

Erwin Hinckley Barbour

University of Nebraska-Lincoln

Follow this and additional works at: https://digitalcommons.unl.edu/geosciencefacpub

Part of the Earth Sciences Commons

Barbour, Erwin Hinckley, "Notice of the Occurrence of Nyctale richardsoni, Richardson's Owl, in Nebraska" (1892). Papers in the Earth and Atmospheric Sciences. 345.

https://digitalcommons.unl.edu/geosciencefacpub/345

This Article is brought to you for free and open access by the Earth and Atmospheric Sciences, Department of at DigitalCommons@University of Nebraska - Lincoln. It has been accepted for inclusion in Papers in the Earth and Atmospheric Sciences by an authorized administrator of DigitalCommons@University of Nebraska - Lincoln. 
December 23. I 892. J

Notice of the Occurrence of Nyctale Richardsoni, Richardson's Owl, in Nebraska.

THE occurrence in this region of Richardson's owl, Nyctale Richardsoni, seems to be entirely established by the recent capture of one in Lincoln. This is a long distance below its soutbern limit, and its appearance is something of a surprise.

However, Professor Lawrence Bruner, who has stuffed and mounted this rare owl, noticed one as a boy, twenty four years ago, near Omaha. Ornithologists at the time questioned the accuracy of his observations, but this specimen confirms the probability of his claim.

The present specimen, which is the first actually taken in the Siate, was captured on 33d Street, in the city of Lincoln, Dec. 12, and was brought alive to the State Museum. It lived but a short time, however, owing perhaps to injuries, or to the heat. The bird is an adult, in fine plumage.

The unexpected appearance of this inhabitant of Arctic regions seems the more striking from the fact that the weather in Nebraska thus far, barring one snow-storm, has been a mild, protracted autumn rather than winter. ERWIN H. BARBOUR.

University of Nebraska, Lincoln, Neb., Dec. 14. 